\title{
MEREFLEKSIKAN INTEGRASI EKS-AGAMA DJAWA SUNDA (ADS) DARI PERSPEKTIF PERTOBATAN KORNELIUS
}

\author{
R.F. Bhanu Viktorahadi a,b,1 \\ ${ }^{a}$ Komunitas Bidang Ilmu (KBI) Teologi Fakultas Filsafat, Indonesia \\ ${ }^{\mathrm{b}}$ Universitas Katolik Parahyangan (UNPAR) Bandung, Indonesia. \\ 1 viktorahadi@yahoo.it
}

\section{Kata-kata Kunci}

ADS,

Petrus,

Kornelius,

dialog,

pertobatan

resiprokal,

identitas.

\begin{abstract}
The Catholic Church often feels uncertain when accepting a group of people who want to convert to Catholicism. Behind this hesitation there are some worries related to the socio-political impacts as well as the quality of faith of the new prospective members. On the other hand, hesitation also come from those who want to join the Catholic Church. These hesitations arise among them because they are anxious to change all the identities they have, especially the ethnocultural identity. The Diocese of Bandung confronts such experiences when receiving some members of Agama Djawa Sunda (ADS) ex-adherents. Reflecting on the encounter between Peter and Cornelius (Acts 10:1-48), some insights can be extracted, especially the need and importance of reciprocal repentance on both sides preceded by an open dialogue process.
\end{abstract}

\section{PENDAHULUAN}

Pada pertengahan 1964 banyak penganut Agama Djawa Sunda (ADS) yang berpusat di Desa Cigugur, Kabupaten Kuningan meminta diri dibaptis menjadi Katolik ${ }^{1}$. Dinamika pertobatan ini terasa sangat signifikan bagi perkembangan Gereja Keuskupan Bandung2. Akan tetapi, di balik sukacita karena bertambahnya saudara-saudara yang menerima diri dibaptis dalam nama Yesus ini, tersimpan sejumlah pertanyaan. Dua pertanyaan men-jadi bahan diskusi tulisan ini. Pertama, bagaimana Gereja menyikapi saudara-saudara yang belakangan bergabung ini, terkait dengan konteks budaya yang mereka miliki. Kedua, bagaimana proses identifikasi Gereja dengan aneka budaya yang menjadi konteks atau latar belakang jemaatnya? Kesaksian Apostolik mencatat bahwa pengalaman yang serupa terjadi pada era jemaat perdana, yaitu ketika Petrus berjumpa dengan Kornelius, seorang Per- wira pasukan Romawi (Kis 10:1-48). Dinamika perjumpaan itu memunculkan suatu pertanyaan dari diri Petrus yang dilontarkannya kepada jemaat Yahudi yang menjadi sidang pendengarnya saat itu, "Bolehkah orang mencegah untuk membaptis orangorang ini dengan air, sedangkan mereka telah menerima Roh Kudus sama seperti kita?" (Kis 10:47).

Bercermin pada pengalaman perjumpaan Petrus dengan Kornelius itu, tulisan ini menjawab kedua pertanyaan tersebut. Pertanyaan tidak akan dijawab dari sudut pandang legalistik. Dalam tulisan ini, pertanyaan dijawab dengan membandingkan peristiwa iman para eks-ADS itu dengan perjumpaan antara Petrus dan Kornelius berikut wacana yang mengikutinya. Jawaban itu sekaligus memberi justifikasi atas semakin menye-barnya Kerajaan Allah dalam peristiwa iman yang terjadi di salah satu sudut bumi Parahyangan itu. 


\section{SEKILAS ADS}

Guna memeroleh gambaran yang memadai untuk mengikuti dinamika bergabungnya banyak eks-ADS ke dalam Gereja Katolik, bagian ini memaparkan secara ringkas definisi ADS dan sekilas ajarannya.

\section{Definisi ADS}

Yang dimaksud dengan Djawa Sunda bukanlah kombinasi atau pencampuran antara budaya Jawa dengan budaya Sunda. Djawa Sunda merupakan singkatan dari "anDJAWAT lan anDJAWAB roh suSUNsuSUN kang den tunDA". Rangkaian kata itu mengandung dua makna yang saling berkait. ${ }^{3}$ Pertama, memilih dan meneruskan pekerjaan yang tertunda dan belum selesai. Kedua, memilih dan menyaring, mengambil dan membuang roh-roh yang terdapat di dalam diri manusia. Dengan ber-Djawa Sunda manu-sia harus sanggup 'mengimani' seluruh roh hurip tanah pakumpulan (= daya hidup tempat di mana dirinya tinggal ${ }^{4}$ dan pengaruhnya yang masuk ke dalam dirinya. Roh-roh atau daya hidup tersebut harus disempurnakan dan diselaraskan dengan kodrat kemanusiaan. Di samping uraian itu, sebagian menyatakan bahwa ADS adalah singkatan dari Atikan Daya Sampur$n a^{5}$ (Pendidikan yang Sempurna).

Selain pemaknaan yang telah disampaikan sebelumnya, istilah 'Sunda' juga mengandung makna lain. Dalam diskusi yang terdapat di dalam buku Pikukuh Tilu Ajaran Karuhun Urang, disebutkan adanya tiga makna istilah 'Sunda' ini. Pertama, falsafah Sunda, yaitu sunda dina geter rasa waruga mancuh jadi panyundaan. Kedua, etnis Sunda, yaitu wujud waruga karsa cipta ti anu Ngersakeun jadi papasten cara-ciri manusa bangsa. Ketiga, letak geografis Sunda, yaitu wates wangen amparan hidupna bangsa. ${ }^{6}$ Tiga butir yang terdapat dalam Pikukuh Tilu Ajaran Karuhun Urang itu dimaknai Pangeran Djati Kusumah secara lebih mendalam. Pendalaman akan ketiga butir itu selanjutnya dideskripsikan secara lebih mendalam dalam tugas akhir Ujang Ma'mun. Pertama, falsafah Sunda menunjuk pada makna istilah 'Sunda' itu sendiri. Menurutnya, makna 'Sunda' adalah bersi- nar. Dalam konteks makna ini, semua orang yang sanggup menyinari orang lain disebut sebagai orang Sunda. Kedua, etnis Sunda menunjuk semua yang tinggal di wilayah Sunda. Secara khusus, wilayah Sunda itu disebut sebagai 'Bumi Pasundan' atau wilayah 'Pasundan'. Ketiga, wilayah letak geografis Sunda menunjuk pada wilayah yang mencakup Sunda Besar dan Sunda Kecil. Yang termasuk Sunda Besar adalah Jawa Barat, Jawa Tengah, dan Jawa Timur. Sedangkan yang termasuk Sunda Kecil adalah Kalimantan, Sulawesi, Irian, dan kepulauan Maluku. Dengan kata lain, wilayah Sunda adalah sebuah kepulauan ${ }^{7}$.

Dalam cakupan yang lebih luas, sebenarnya istilah orang Sunda juga seringkali masih terus didiskusikan, terutama di kalangan budayawan. Dibandingkan dengan telaah-telaah tentang manusia atau kebudayaan Jawa, telaah tentang manusia dan kebudayaan Sunda tidak banyak. Pada masa sebelum perang ada sebuah buku karya $\mathrm{H}$. Hasan Mustapa berjudul "Bab Adat-adat Urang Priangan jeung Sunda lianna ti eta" (1913). Buku ini telah diterjemahkan ke dalam bahasa Belanda oleh R.A. Kern (1946). Di samping itu, ada sebuah tulisan karya Dr. K.A.H. Hidding berjudul "Gebruiken en Godsdienst der Soendanezen" (1935).

Pada masa setelah perang ada telaah yang dilakukan seorang sarjana Amerika bernama Robert Wessing berjudul "Cosmology and Social Behaviour in a West Javanese Settle-ment" (1978). Sebuah buku lagi tentang Sunda juga muncul usai perang, yaitu "Masyarakat dan Kebudayaan Sunda" (1980). Buku ini disunting Dr. Edi S. Ekajati. Kelangkaan hasil-hasil telaah tentang manusia dan kebudayaan Sunda itu niscaya menyulitkan orang yang bermaksud menulis uraian tentang manusia Sunda. ${ }^{8}$ Akan tetapi, kesulitan mengiden-tifikasi orang Sunda itu justru membuka peluang bagi pelbagai penelitian lanjutan yang semakin mendalam atas identitas orang Sunda ini.

\section{Sekilas Ajaran ADS}

Ber-agama Djawa Sunda mengandung makna senantiasa berusaha semakin mengenali kesejatian dirinya sendiri dan men- 
jalani hidup selaras dengan kodratnya sebagai manusia berdasarkan ukuran-ukuran hidup manusia yang sejati. Dengan semakin meng-enali dirinya, manusia akan semakin mengenal Allah Penciptanya. Bagi para penganut ADS, agama menjadi upaya mendekatkan diri mereka sebagai manusia kepada 'Aku-nya yang sejati'. Bersamaan dengan upaya tersebut terlaksanalah upaya mendekatkan dirinya pada asal kehidupan yang sejati, yaitu Allah Sang Penciptanya..$^{9}$ Bagi para penganut ADS, agama tidak bisa sekadar dilihat dari keluhuran ajarannya. Agama sungguh menjadi pegangan hidup justru dari realisasinya dalam pekerjaan atau tindakan konkret. Disebutkan dalam salah satu dasar ajaran ADS bahwa "Agama sanajan luhur ajaranana, tapi lamun teu dipigawe, teu diamalkeun atanapi didarigamakeun, tangtuna moal aya gunana, moal karasa mangpaatna...." 10 Artinya, "meski-pun agama memiliki ajaran yang luhur, jika tak dilaksanakan atau diamalkan dalam kehidupan nyata, tentu tak akan berguna, tak bermanfaat...". ${ }^{11}$ Sebuah catatan ajaran ADS memperjelas tekanan penghayatan ajaran dalam tindakan konkret, $^{12}$ dalam uraian "Sadayana nu kaukur djadi kasaean, sing tiasa milampah $k u$ djalan panggawe anu sae. Sae pangutjapna, sae rengkak polahna, kedah sabarengna saena sir, rasa, pikiran, akad itikadna. Sawangsulna singkahan panggawe anu awon..." Artinya, segala sesuatu yang terujar sebagai kebaikan, lakukanlah dengan pekerjaan atau perbuatan yang baik. Baik ucapannya, tingkah lakunya, harus seiring dengan sir, rasa, pikiran, akad itikad yang baik. Sebaliknya hindarkanlah pekerjaan-pekerjaan yang buruk.... ${ }^{13}$ ADS mengajarkan dan mempercayai adanya Tuhan Yang Maha Esa, yang sering disebut 'Pangeran sikang sawiji-wiji.' Para penganut ADS menyembah Tuhan dengan bersemedi singkat, membulatkan dan mengarahkan segala perasaan dan pikiran batin menuju sesuatu yang jauh berada di dalam 'aku'-nya atau 'ingsun'-nya atau 'kuring'nya. ${ }^{14}$ Dengan semedi itu, setiap penganut ADS harus sanggup berdialog dengan 'aku'nya.

\section{EKS-ADS MENJADI KATOLIK}

Setiap pilihan keputusan yang baik senantiasa didorong sejumlah motivasi yang kuat di baliknya. Demikian pula, peristiwa bergabungnya banyak eks-ADS ke dalam Gereja Katolik didorong sekurang-kurangnya dua motivasi. Pertama, motivasi sosial-politis. Kedua, motivasi religius. Uraian berikut ini memaparkan kedua motivasi secara ringkas.

\section{Motivasi Sosial-Politis}

Sebagai suatu agama lokal, ADS terbentuk pada 1848. Pendirinya adalah seorang keturunan Pangeran Alibasa I, Sultan Gebang, Cirebon Timur, bernama Pangeran Sadewa Madrais Alibasa Kusuma Widjaja Ningrat. Nama Madrais diperolehnya untuk menghindarkan dirinya dari incaran pemerintah Belanda saat dititipkan kepada Ki Sastra-wadana. ${ }^{15}$ Sumber lain menyebutkan bahwa nama Madrais berasal dari Muhammad Rais, nama yang identik dengan budaya Islam. Disebutkan pula bahwa nama Madrais ini berasal dari ungkapan 'maduning rasa ing sajati'. Artinya, manusia dengan pengertian dan perasaan yang sejati, semangat berbela rasa dan keluhuran budi. ${ }^{16}$ Pangeran Madrais ini adalah putera dari pernikahan Pangeran Alibasa I dengan R. Kastewi, keturunan kelima Tumenggung Jayadipura Susukan. Sebagai seorang bangsawan, pangeran kelahiran Susukan, Gebang Udik, Kuningan Timur pada 1835 ini mengajarkan dan mengembangkan keutamaan-keutamaan hidup yang diyakini-nya kepada orang-orang yang dijumpainya. Upaya pangeran yang dalam silsilah keluarganya juga disebut Pangeran Surya Nata atau Pangeran Kusuma Adiningrat ini kerap tersandung, bahkan terhalang kesukaran akibat fitnah yang ditimpakan kepadanya.

Fitnah-fitnah yang ditimpakan kepadanya antara lain 'anak jadah', seorang murtad, seorang kafir, penyembah berhala, dan kaki tangan Residen Cirebon. Fitnah-fitnah ini membuatnya sangat menderita. Penderitaan yang dialaminya tidak hanya secara batin. Akibat fitnah-fitnah itu ia harus merasakan masuk-keluar penjara tanpa melalui 
proses pengadilan yang benar. Puncak penderitaannya, terjadi para periode 1901 sampai dengan 1908. Pada periode kelam tersebut, ia merasakan pembuangan di Boven Digoel, tempat pengasingan orangorang yang dianggap penjahat pada zaman Hindia Belanda.

Untuk menggambarkan kengerian tempat pembuangan itu, sastrawan Pramoedya Ananta Toer melukiskan Boven Digoel pemukiman tetap yang dirancang pemerintahan penjajah Belanda sebagai permukiman tetap para tahanan politik (Tapol). Akan tetapi, sebagai permukiman, sarana yang tersedia sangatlah minim. Biaya makan untuk sebanyak 2.233 orang buangan, pejabat, dan narapidana, yang hampir mencapai f 1.000 setahun luar biasa besar pada masa itu. Bagi para buangan sendiri, tinggal di Digoel adalah malapetaka. Selain mendapat perlakuan yang kasar, kerja paksa membabat hutan dan membuka perladangan adalah tugas maha-berat. Sejak tahun pertama kedatangan para buangan pada 1927, berbagai penyakit mulai menyerang. Antara lain, disentri, beri-beri, dan tiga jenis malaria.

Di antara penyakit tersebut yang paling berbahaya adalah malaria hitam. Orang setempat memastikan bahwa jika air kencing seseorang sudah mulai berwarna hitam, pertanda ajal sedang menjemput. Sementara itu, wilayah di luar permukiman para Tapol itu juga tidak kalah berbahaya. Wilayah itu dikuasai oleh suku-suku Papua pemenggal dan pemakan orang ${ }^{17}$. Walaupun banyak mengalami penderitaan selama dibuang, Pangeran Alibasa tidak pernah berhenti menyebarkan keyakinannya sampai wafat pada 1940 di Cigugur ${ }^{18}$.

Setelah wafatnya, tampuk pimpinan ADS dipegang dan dilanjutkan puteranya, Pange-ran Tedja Buana Alibasa Kusuma Widjaja Ningrat yang tinggal di Cirebon. Pada tahun-tahun awal kepemimpinannya, Pangeran Tedja Buana sudah harus berhadapan dengan penjajahan dan penindasan Jepang (1942-1945). Pihak-pihak yang menginginkan bubarnya ADS memanfaatkan pemerintahan militer Jepang untuk semakin memojokkan keberadaan ADS. Dengan pelbagai bentuk ancaman dan teror kekerasan, para penganut ADS dipaksa untuk menanggalkan dan meninggalkan kepercayaannya. Akibat teror itu, Pangeran Tedja Buana terpaksa harus mengungsi. Dalam pengungsiannya, sejumlah kota sempat disinggahinya, yaitu Bandung, Garut, dan Tasikmalaya. Di setiap daerah yang disinggahinya, jumlah pengikut ADS bertambah, walaupun tidak banyak. Akhirnya Pangeran Tedja Buana sekeluarga mengungsi ke Ciputri (dua kilometer dari Cigugur ke arah barat) sampai keadaan normal. ${ }^{19}$

Pada suatu hari di pertengahan 1964 seorang penganut ADS tertangkap tangan saat melakukan perbuatan yang menyimpang dari ajaran ADS. Orang itu dianggap menistakan agama Islam. Oknum-oknum tertentu yang sejak lama tak menyukai ADS segera memanfaatkan peristiwa tersebut. Mereka yang sejak lama menginginkan dibubarkannya ADS ini menyebarkan rumor-rumor negatif tentang ADS. Sejumlah tokoh ADS, termasuk Pangeran Djatikusumah, ditahan dan diperiksa. Akan tetapi, sejumlah simpati datang dari beberapa tokoh, termasuk dukungan moral dan bantuan hukum dari Ketua Mahkamah Agung saat itu ${ }^{20}$.

Akibat peristiwa tersebut, para pengikut ADS, terutama yang jauh dari kota, merasakan kondisi yang sangat panik. Mereka panik karena merasa dikejar-kejar dan dihantui perasaan tak aman. Pada 9 September 1964 Gedung Pusat ADS (Keraton Cigugur - sekarang gedung Cagar Budaya Nasional Paseban Tripanca Tunggal) disegel Kejaksaan Kabupaten Kuningan. Para penganut ADS pun dilarang melakukan pertemuan. Padahal, ADS sendiri pada saat itu bukan merupakan suatu keyakinan terlarang ${ }^{21}$. Puncak kepanikan para penghayat ADS terjadi saat semakin kuatnya tekanan terhadap mereka terkait tidak sahnya perkawinan yang mereka laksanakan karena tata cara perkawinan ADS tidak termasuk tata cara perkawinan yang legal dalam hukum Indonesia. Keputusan tersebut dikeluarkan Peninjau Aliran Kepercayaan Masyarakat (PAKEM) Kabupaten Kuningan yang didirikan Departemen Agama RI pada Juni $1964^{22}$. Alasan-alasan sosial-politis dan nantinya ditambah alasan religius inilah yang mendorong para penga- 
nut ADS ini berniat memberi diri dibaptis menjadi bagian dari Gereja Katolik.

\section{Motivasi Religius}

Puncak kepanikan ini justru menjadi blessing in disguise -petaka yang membawa rahmat bagi para penghayat dan Gereja. Moment tersebut justru menjadi pintu masuk perjumpaan ADS dengan Gereja Katolik. Kontak pertama para penghayat ADS dengan Gereja Katolik terjadi saat seorang penganut ADS bernama Sakim memohon kepada Gereja untuk dibaptis menjadi seorang Katolik. Ia berharap dengan menjadi Katolik, status perkawinannya bisa menjadi sah. Legalitas perkawinan sangat diperlukannya karena ia adalah seorang pegawai negeri. Akan tetapi, saat itu imam yang bertugas agak berhati-hati dalam menanggapi permohonan tersebut karena kuatir adanya permasalahan politik di baliknya ${ }^{23}$.

Sementara itu, pimpinan ADS, Pangeran Tedja Buana dalam kondisi sakit. Sakit yang dideritanya ini cukup parah. Akibat kondisinya ini, ia tak bisa memenuhi panggilan untuk bersaksi dari kantor Kejaksaan Kabupaten Kuningan terkait sejumlah kasus yang menim-pa ADS dan para pengikutnya itu. Dalam keadaan sakit, Pangeran Tedja Buana men-datangi Pastor Ambrosius Hidayat Sasmita OSC, imam yang bertugas di Paroki St. Yusuf, Cirebon untuk memohon perlindungan, terutama dari kejaran pihak kejaksaan. Dengan alasan cinta kasih, Pastor Hidayat memperkenankan Pangeran Tedja Buana tinggal di Pastoran Paroki Santo Yusuf Cirebon selama sakit. Tak hanya sekadar tinggal, Pangeran Tedja Buana juga mendapatkan perawatan medis dari dokter Katolik.

Pada pertengahan September 1964, sementara Pangeran Tedja Buana mendapatkan perawatan di Pastoran Paroki Cirebon, tiba-tiba tersebar berita tentang adanya surat pernyataan darinya bahwa Pimpinan ADS membubarkan ADS. Selanjutnya, Pangeran Tedja Buana dan keluarganya menerima diri dibaptis menjadi umat Katolik tanpa paksaan dari pihak mana pun. Pernyataan ini bagaikan petir di siang bolong bagi para penganut ADS, para gembala Gereja, pejabat pemerintahan, jurnalis, dan masya- rakat luas. Walaupun sangat terkejut, sesudah mendapatkan penjelasan dari pimpinannya, ribuan penganut ADS pun berbondong-bondong mengunjungi pastoranpastoran wilayah mereka masing-masing untuk menerima diri dibaptis.

Pelajaran agama (katekese) pun diberikan kepada mereka. Akan tetapi, mengingat begitu banyaknya calon, katekese dilakukan terlebih dahulu kepada para tokoh. Setelah dibaptis, tokoh-tokoh inilah yang memberikan kate-kese kepada eks penganut ADS itu. Selanjutnya, pendalaman iman dilaksanakan para imam dan katekis. Karya ini tidaklah mudah karena mendapat sorotan eksternal sehingga memerlukan kesabaran, ketrampilan, dan keberanian ${ }^{24}$. Perayaan Ekaristi perdana di desa Cigugur diselenggarakan pada Hari Raya Natal 1964. Pada Januari 1965, Pastor M. Kuppens OSC ditugaskan ke Cigugur untuk tinggal di tengah umat baru ini. Beberapa bulan kemudian menyusullah Pastor W. Straathof OSC pada Mei 1965 dan Pastor A. Rutten OSC pada Juli $1965^{25}$.

Ada sejumlah alasan yang mendorong pemimpin ADS masuk Agama Katolik. Pertama, ajarannya paralel dengan ajaran ADS, terutama perkawinan dan sunat. Kedua, semangat cinta kasih Tuhan yang dihidupi umat Katolik. Ketiga, kenyataan menunjukkan bahwa kehidupan umat Katolik benarbenar menunjukkan budi mereka yang luhur dan saleh. Keempat, agama Katolik dilahirkan Tuhan sendiri melalui Putera-Nya. Kelima, adanya amanat-amanat atau nubuat-nubuat dari pendiri ADS dahulu, jauh sebelum ADS dibubarkan, bahwa kelak di kemudian hari akan tiba saatnya ADS akan 'lahir kedua kalinya di bawah Cemara Putih'. Nubuat ini dimaknai bersatu dengan Kato$\mathrm{lik}^{26}$. Merasakan banyaknya keselarasan antara ajaran ADS dengan ajaran Katolik ini membuat eks-penganut ADS ini meyakinkan diri menerima diri dibaptis menjadi seorang pengikut Kristus dalam Gereja Katolik.

\section{MENEROPONG PENGALAMAN PETRUS}

Narasi pewartaan Kabar Gembira sekaligus pertobatan kepada iman akan Kristus tidak hanya meluas, tetapi juga mendalam. 
Dalam pertobatan orang-orang eks-penganut ADS menjadi jelas bahwa upaya memperkenalkan iman akan Kristus tak bisa dilaksanakan dengan paksaan. Waktu yang terpakai dalam proses pertobatan itu pun tak singkat. Dibutuhkan cara yang santun dan dalam kurun waktu yang tak sedikit. Iman membutuhkan pengenalan, pemahaman, dan penghayatan. Oleh karena itu, iman tak pernah bisa dipaksakan diterima apalagi dalam waktu yang singkat.

Pertobatan orang-orang eks-penganut dan penghayat ADS menjadi suatu model bagaimana iman akan Kristus itu dikenalkan dan ditawarkan. Upaya ini menjadi salah satu wujud nyata misi yang dijalankan para Rasul dalam menjalankan amanat Kristus supaya pergi sampai ke ujung dunia untuk mewartakan Kabar Gembira-Nya. Dinamika inilah yang dialami Petrus saat berjumpa dengan Kornelius. Tujuan awal perjumpaan itu adalah pertobatan Kornelius. Akan tetapi, yang terjadi pada praktiknya adalah pertobatan resiprokal, yaitu pertobatan Kornelius ke dalam penghayatan lebih dalam akan Yesus sebagai Mesias dan sekaligus perto-batan Petrus ke dalam penyingkapan karya keselamatan Allah bagi bangsa-bangsa (nonYahudi).

\section{Perjumpaan Petrus dan Kornelius}

Seperti sudah berulang kali disimak dan dibahas, ungkapan "pergi dan menyeberang sampai ke ujung bumi' merupakan suatu usaha yang mengandung banyak konsekuensi. Salah satu pertanyaan yang harus dijawab adalah bagaimana pewartaan kepada bangsa-bangsa lain bisa dipertanggungjawabkan. Guna memahami ungkapan tersebut, Teks Kis 10:1-48 menjadi gambaran jelas bagaimana memahami perutusan kepada bangsa lain.

Teks Kis 10:1-48 dalam Alkitab diberi judul 'Petrus dan Kornelius'. Kisah ini bisa dibagi menjadi empat bagian. ${ }^{27}$ Pertama, teks Kis 10:1-8. Bagian memuat penglihatan Kor-nelius di Kaisarea. ${ }^{28}$ Dalam penglihatan yang dialaminya, malaikat menyuruh Kornelius untuk memanggil Petrus yang sedang berada di Yope. Kedua, teks Kis 10:918. Perikop ini berisi penglihatan Petrus.
Petrus melihat benda seperti kain lebar diturunkan sampai ke tanah. Di dalamnya terdapat aneka jenis binatang. Tak diketahui binatang apa saja yang ada di sana. Akan tetapi, dari jawaban Petrus bisa diduga bahwa yang ada di sana adalah binatang-binatang najis. Binatang-binatang semacam itu harus dihindari setiap orang yang mengaku sebagai seorang Yahudi tulen dan saleh. Saat diperintahkan untuk menyembelih dan memakannya, Petrus lang-sung menolak mentah-mentah. Alasannya, binatang-binatang itu haram. Akan tetapi, suara dari sorga pun segera terdengar. "Apa yang dinyatakan halal oleh Allah, tidak boleh engkau nyatakan haram" (Kis 10:15). Dikatakan bahwa peristiwa turunnya suara itu terjadi sampai tiga kali.

Ketiga, teks Kis 10:19-23. Di dalam perikop ini dilukiskan perjumpaan antara Petrus dengan utusan Kornelius. Saat Petrus sedang merenungkan pengalamannya, utusan Korne-lius datang menghampirinya. Utusan tersebut langsung menyampaikan maksudnya untuk membawa Petrus ke Kaisarea. Keempat, teks Kis 10:24-43. Teks ini memuat kisah pertemuan Petrus dan Kornelius. Petrus menyadari bahwa sebenarnya dirinya sebagai orang Yahudi tak boleh bergaul dengan orang non-Yahudi. Akan tetapi, oleh karena Allah yang memerintahkannya, ia pun harus melakukannya (Kis 10:28). Petrus akhirnya menyadari bahwa keselamatan Allah melalui Yesus Kristus juga diperuntukkan bangsa-bangsa lain. Dengan demikian, pertanyaan, "Bolehkah orang mencegah untuk membaptis orang-orang ini dengan air, sedangkan mereka telah menerima Roh Kudus sama seperti kita?" (Kis 10:47) terjawab.

\section{Pentakosta Kaisarea}

Pembaptisan Kornelius oleh Petrus merupakan peristiwa penting bagi perkembangan jemaat. Petrus menjadi wakil jemaat Yerusalem yang merupakan Gereja Induk. Sementara itu, Kornelius adalah seorang Roma, seorang non-Yahudi. Dalam teks Kis 11:1-18 dikisahkan bahwa Petrus mempertanggungjawabkan baptisan Kornelius di hadapan orang-orang bersunat di Yeru- 
salem. "Jadi, jika Allah memberikan karunia yang sama kepada mereka seperti kepada kita pada waktu kita percaya kepada Tuhan Yesus Kristus, bagaimana mungkin aku mencegah Dia?" (Kis 11:17). Dengan demikian, pembaptisan Kornelius merupakan legitimasi dari Gereja Induk untuk mewartakan kabar suka-cita kepada bangsa-bangsa lain. Allah memang menghendaki demikian. Jalan menuju perutusan kepada bangsabangsa mendapatkan lampu hijau dari Gereja Yerusalem. Dengan demikian satu dimensi dari ketegangan antara budaya Yahudi dengan budaya asing tersele-saikan. Dari pihak tradisi Yahudi kini tak ada lagi keberatan untuk menerima orang asing.

Menurut sebagian besar penafsir, kisah perjumpaan Petrus dan Kornelius ini memenuhi syarat pola pentakostal. ${ }^{29}$ Dengan demikian, perjumpaan ini boleh menyandang sebutan 'Pentakosta di Kaisarea'. Pentakosta di Kaisarea ini merupakan Pentakosta yang ketiga dalam Kisah Para Rasul. Yang pertama adalah yang terjadi atas para Rasul (Kis 2). Yang kedua terjadi di antara jemaat (Gereja) Yerusalem yang teraniaya (Kis 4:31). Pentakosta ini sekaligus merupakan Pentakosta orang-orang tak bersunat. Petrus menyatakan bahwa mereka pun menerima Roh Kudus “... sama seperti kita” (Kis 10:47), “ ... sama seperti dahulu ke atas kita" (Kis 11:15). Berdasarkan perlakuan Allah yang sama baik terhadap para Rasul maupun terhadap golongan tidak bersunat itu, Petrus membuat kesimpulan yang diungkapkannya melalui pertanyaan. "Bolehkah orang mencegah untuk membaptis orang-orang ini dengan air, se-dangkan mereka telah menerima Roh Kudus sama seperti kita?" (Kis 10:47). Setelah itu, Petrus menyuruh membaptis Kornelius dalam nama Yesus dan tinggal beberapa hari bersamanya (Kis 10:48). ${ }^{30}$

Setelah itu, Lukas sebagai penulis Kisah para Rasul berbicara tentang perbantahan yang timbul di kalangan saudara-saudara (yang tinggal) di Yudea (Kis 11:1), di kalangan bersunat yang merupakan jemaat Yerusalem (Kis 11:2) akibat inisiatif Petrus tersebut. Ungkapan-ungkapan perbantahan itu muncul dalam sejumlah ayat. Misalnya,
"Engkau telah masuk ke rumah orang-orang yang tidak bersunat dan makan bersamasama dengan mereka" (Kis 11:2). Sebagai suatu tanggapan Petrus, memberikan suatu penjelasan dalam wujud suatu wacana pembinaan kepada jemaat (Kis 11:5-17). "Tetapi Petrus menjelaskan segala sesuatu berturut-turut, katanya: "Aku sedang berdoa di kota Yope ..."

Dalam wacananya, Petrus mengulang yang telah dikisahkan Lukas. Dalam wacana tersebut muncul penglihatan tentang kain lebar dan penolakan Petrus untuk menajiskan diri dengan segala sesuatu yang haram (Kis 11:5-10), kedatangan utusan Kornelius dan perjalanan menuju Kaisarea (Kis 11:1112), kisah Kornelius tentang diri Petrus (Kis 11:13-14), wacana kepada Kornelius dan interupsi terhadap wacana oleh Pentakosta orang-orang tak bersunat (Kis 11:15), dan konsekuensi ketaatan Petrus pada kehendak Allah (Kis 11:17). ${ }^{31}$

Pengulangan teks Kis 10 dalam teks Kis 11 memunculkan tiga hal. Pertama, mengungkapkan terjadinya peristiwa terse-but menurut cakrawala pandang Petrus. Perlu dicermati bahwa urutan dua penglihatan sebenarnya terbalik. Yang pertama dikisahkan seharusnya penglihatan Petrus ini. Kedua, membawa pembaca menyadari langkah besar yang dilakukan Petrus dan pentingnya langkah tersebut. Ketiga, merekam 'pertobatan' Gereja Yerusalem yang dilambangkan dengan 'pertobatan' Petrus. ${ }^{32}$ Hal terakhir ini menjadi jelas jika ayat-ayat awal dikonfrontasikan dengan ayat-ayat akhir. Pada teks Kis 11:2-3 diungkapkan secara jelas pertobatan itu. "... Ketika Petrus tiba di Yerusalem, orang-orang dari golongan yang bersunat berselisih pendapat dengan dia. Kata mereka: "Engkau telah masuk ke rumah orang-orang yang tidak bersunat dan makan bersama-sama dengan mereka." Sedangkan pada teks berikutnya diungkapkan situasi yang terjadi dalam diri jemaat setelah mengetahui kehendak Allah untuk menyelamatkan semua bangsa itu. "Ketika mendengar hal itu, mereka menjadi tenang, lalu memuliakan Allah, katanya: 'Jadi kepada bangsa-bangsa lain juga Allah menga- 
runiakan pertobatan yang memimpin kepada hidup"” (Kis 11.18).

Sesudah kisah pertobatan ganda dan resiprokal ini, dikisahkan bagaimana karya perutusan ke daerah non-Yahudi mulai terlaksana. Barnabas dan Saulus ke Antiokhia (Kis 11:19-30). Dikatakan bahwa di Antiokhialah murid-murid itu untuk pertama kalinya disebut Kristen (Kis 11:26b). Kemudian mere-ka berangkat ke Siprus (Kis 13:4-12), ke Antiokhia di Pisidia (Kis 13:1349), ke Ikon-ium, Listra dan Derbe (Kis 13:50-14:20). Ini adalah perjalanan misi Paulus yang pertama.

\section{DUA JALUR IDENTIFIKASI}

Dari sudut pandang kisah perjumpaan Petrus dengan Kornelius ini, pertobatan dialami kedua belah pihak. Pihak pertama yang mengalami pertobatan adalah Kornelius. Pihak kedua adalah Petrus.

\section{Membongkar Kepicikan}

Sebagaimana orang-orang yang baru mengenal Kristus, Kornelius terpesona dengan hal-hal ajaib yang terjadi berkat kuasa nama Yesus melalui para Rasul. Keterpesonaan ini menghantarkannya untuk memberi diri dibaptis dalam nama Yesus. Pihak kedua yang mengalami pertobatan adalah Petrus. Sebagai wakil Gereja Induk sekaligus tradisi apostolik yang mengalami langsung perjumpaan dengan Kristus, awalnya Petrus masih terperangkap gagasan dan pemikiran bahwa yang bisa dan patut diselamatkan hanyalah mereka yang memiliki akar Yahudi. Perjumpaan dengan Kornelius yang diawali dengan turunnya kain berisi binatang-binatang haram disertai perintah Allah mempertobatkan Petrus. Kepicikan pandangannya dibongkar. Petrus disadarkan bahwa keselamatan yang ditawarkan Kristus melalui pertobatan dan pembaptisan juga boleh dialami dan dirasakan semua orang dari kalangan mana pun.

Sudut pandang ini menjustifikasi peristiwa bertobatnya para eks-penganut dan penghayat Agama Djawa Sunda (ADS) di Kuningan dan sekitarnya pada pertengahan 1964. Walaupun pada saat itu imam yang bertugas agak berhati-hati dalam menang- gapi permohonan tersebut karena kuatir adanya permasalahan politik di baliknya, ${ }^{33}$ pintu pada pembaptisan tetaplah dibuka lebar-lebar. Gereja Cirebon sebagai wajah Gereja universal dalam konteks integrasi eks-penganut ADS saat itu berani meninggalkan keraguan dan kekuatirannya. Keraguan dan kekuatiran itu lantas bertransformasi menjadi keberanian untuk membuka diri pada saudara-saudara baru yang rindu akan pembaptisan dalam nama Kristus.

Kedua pihak bertobat. Para eks-penganut dan penghayat ADS layaknya Kornelius bertobat karena terpesona pada keajaiban Kristus melalui para utusannya. Sebaliknya, Gereja setempat juga bertobat. Artinya, Gereja mau membuka diri, meninggalkan keraguan dan kekuatirannya, lantas mencari jalan yang lebih lapang supaya orang-orang dari latar belakang apa pun bisa ikut serta, bahkan melibatkan diri dalam rencana keselamatan Allah.

Akan tetapi, dinamika pertobatan resiprokal itu tidak terjadi dengan mudah. Narasi pertobatan itu menunjukkan bahwa saat penganut ADS meminta diri dibaptis, timbul keraguan dari imam yang dijum-painya. Imam tersebut kuatir jika permin-taan itu dikabulkan akan timbul permasa-lahan sosial-politik. Di samping itu, tentu imam tersebut memandang jauh ke depan terkait sejumlah hal yang harus dilakukan Gereja jika permintaan untuk dibaptis itu dikabulkan. Dalam hal ini sangat penting untuk tetap menjaga kebenaran ajaran Gereja sekaligus menjaga keluhuran nilai-nilai baik yang telah dihayati para eks-penganut ADS itu. Merujuk pada pendapat para ahli fenomenologi, terutama Edmund Husserl, filsuf Belanda, Herman Dooye-weerd telah menunjukkan betapa penting-nya menjaga keluhuran akar-akar keaga-maan dan kehidupan rohani manusia. ${ }^{34}$

Memang, dalam perkembangannya sebagian komunitas eks-penganut ADS yang melebur ke dalam Gereja Keuskupan Bandung ini mengambil bagian yang penting dalam perjalanan sejarah iman Keuskupan Bandung, walaupun di sejumlah sisi masih banyak yang perlu dicermati. Menulis pada 
1994, A. Rutten mengemukakan pernyataannya dalam kesem-patan peringatan dasawarsa karya peng-gembalaan Mgr. A. Djajasiswaja sebagai Uskup Keuskupan Bandung.

\begin{abstract}
"Kita harus mengakui bahwa Gereja Katolik di Jawa Barat mengalami kegagalan, walau tidak benar kalau mengatakan gagal total. Kalaupun kita harus menerima bahwa Gereja Katolik belum berakar di Tatar Sunda ini, kita tetap dapat menunjukkan bahwa sudah ada akar-akar yang memberi harapan untuk masa depan. Yang saya sebutkan di sini adalah imam asli Sunda ada sembilan orang. Katekis sebelas orang. Suster sudah lima orang; di seminari tinggi masih ada delapan calon imam asli Sunda. Sudah ada puluhan sarjana dengan di antaranya beberapa dosen, ratusan guru di swasta dan di negeri, ratusan perawat dan seterusnya."
\end{abstract}

Pastor Rutten memaklumi bahwa umum-nya paroki-paroki di Keuskupan Bandung tak tertarik untuk memakai liturgi gaya Sunda karena jumlah umat Sunda relatif sedikit, kecuali di Cigugur. Akan tetapi, liturgi gaya Sunda pasti didambakan sekelompok Katolik Sunda, supaya seluruh pribadinya dapat mengungkapkan diri dan tersentuh dalam bersama-sama memuliakan Tuhan dan merayakan liturgi. Untuk menjadi Katolik, jangan sampai mereka harus meninggalkan kesundaan. Tak cukup diadakan liturgi gaya Sunda, tetapi seluruh hidup Gereja Keuskupan Bandung harus mencari kontak dengan masyarakat setempat dan harus menjadi 'Gereja gaya Sunda'. Orang Sunda akan dapat merasa at home dalam Gereja Katolik, dengan kemungkinan ada lagi yang menggabungkan diri. Alangkah menyenangkan kalau disambut dengan cara yang menyenangkan, dengan bahasa yang akrab dan gaya hidup yang sesuai. ${ }^{35}$

Harapan Pastor Rutten pada saat itu dilihat sebagai suatu keprihatinan serius yang harus terus-menerus ditanggapi Gereja Keuskupan Bandung. Keprihatinan sekaligus harapan itu terus menjadi materi diskusi dalam sejumlah agenda pertemuan baik di tingkat keuskupan maupun paroki di Keuskupan Bandung. Tanggapan yang paling terkini tertuang dalam Kebijakan Pastoral Keuskupan Bandung sebagai hasil Sinode
Keuskupan Bandung 2015. Sinode yang melibatkan seluruh elemen umat Keuskupan Bandung itu menghasilkan 37 kebijakan pastoral. ${ }^{36}$ Salah satu di antara kebijaksanaan itu adalah 'Dialog Budaya Lokal dan Liturgi'. Ditetapkan dalam butir ke-28 kebijakan pastoral itu bahwa umat Allah Keuskupan Bandung memastikan umat di tempat perutusannya masing-masing semakin melibatkan diri untuk menggali nilai-nilai kearifan budaya lokal yang sesuai dengan nilai-nilai Gereja, termasuk dalam kehidupan liturgi ${ }^{37}$. Dalam pengantar hasil Sinode Keuskupan Bandung 2015, Uskup Bandung, Mgr. Antonius Subianto Bunjamin OSC menegaskan bahwa sinode itu dipahami sebagai berjalan bersama dalam menghidupi iman akan Kristus yang direflek-sikan, didiskusikan, dan dipikirkan guna menentukan kebijakan keuskupan untuk 25 tahun mendatang ${ }^{38}$. Dengan kata lain, upaya Gereja Keuskupan Bandung untuk membuka diri terhadap masyarakat dan budaya setempat akan terus dilaksanakan secara serius sekurang-kurangnya sampai 25 tahun ke depan sejak Sinode 2015 itu.

\section{Persoalan Identitas}

Yang muncul akibat bergabungnya sejumlah eks-penganut ADS itu adalah persoalan identitas. Sejauh mana identitas Sunda bisa masuk ke dalam Gereja. Pada saat yang sama, sejauh mana Gereja bisa mengakomodasi budaya Sunda itu dalam dirinya supaya mereka yang baru bergabung itu merasa sungguh-sungguh diterima dan menjadi bagian tak terpisahkan dari Gereja. Kiranya, dalam hal ini Gereja bisa mendapatkan dua jalur iden-tifikasi imannya. Pertama, jalur vertikal. Yang dimaksud jalur vertikal adalah tradisi budaya yang diterimanya sebagai warisan dan Tradisi Gereja Katolik pada umumnya. Kedua, jalur horisontal. Yang dimaksud jalur horisontal adalah pilihan-pilihan gaya hidup sebagai orang kristiani di tengah masyarakat. Kristi-anitas sendiri dapat menjadi pilihan hori-sontal bagi masyarakat setempat.

Adanya dua jalur itu tidak menggiring Gereja pada polarisasi biner. Menjadi Gereja bukan berarti sibuk dengan identifikasi apa 
yang asli dan murni dalam Gereja dan menghapus segala macam unsur lain yang terdapat dalam budaya lokal. Gereja juga tak perlu jatuh pada ideologisasi karakter sebagai umat Kristiani, yang seolah-olah unggul mengatasi semua identitas diri lainnya. Diupa-yakan supaya tidak sampai terjadi chauvinis kristen yang lupa bahwa kekristenan bukanlah perkara mengagungkan identitas sendiri dan menyerang identitas lainnnya. Kekristenan pastinya ditentukan dari ekspresi pola bersikap dan berperilaku atau 'tatasusila yang diterima berdasarkan iman' dalam perkataan dan perbuatan. ${ }^{39}$ Di samping itu, iman kristiani juga tidak boleh menutup diri pada nilainilai baik yang terdapat di dalam kepercayaan di luar kristianitas sebagaimana telah dinyatakan para Bapa Konsili dalam dokumen "Nostra Aetate".

Dengan kata lain, perwujudan iman senantiasa mencari konkretisasinya dengan menyelaraskan dirinya dengan situasi, kondisi, keprihatinan, dan harapan setempat di mana iman itu hidup. Tidak ada definisi kekristenan absolut, sebab kebudayaan itu pada dirinya adalah relatif. Ada suatu kebutuhan bersama-sama antara kebudayaan dan kekristenan. ${ }^{40}$ Dari dinamika perjumpaan antara iman dan budaya setempat, akan muncul teologi dunia, tetapi tidak dari satu konteks yang memaksakan teologinya kepada konteks-konteks yang lain sebagaimana yang telah terjadi pada waktu yang lalu oleh teologi Barat. Teologi dunia akan tercipta apabila konteks yang bermacammacam itu berkumpul bersama dan berbagi pengalaman dengan sikap saling menghargai. ${ }^{41}$

Perwujudan konkret iman dalam budaya setempat itu akan terus berkembang. Bangunan berteologi itu suatu proses tanpa akhir, sebab teologi kontekstual yang dihasilkan itu selalu bersifat sementara karena pengetahuan mengenai pesan alkitabiah adalah terbatas dan pengalaman dalam suasana kebudayaan yang berubah selalu relatif. ${ }^{42}$ Akar budaya setempat sebagai tempat tumbuh dan berkembangnya benih iman itu harus selalu diperhatikan.
Dalam upaya mengejar dan memeroleh kebenaran iman, tak hanya kebenaran doktrinal yang harus diperhatikan. Cara hidup seorang beriman akan jauh lebih menunjukkan sejauh mana ia memang memahami dan menghayati imannya tersebut. Dalam hal ini, Thomas Merton, seorang rahib dan mistikus modern menyatakan bahwa walaupun pada tingkat filsafat dan formulasi-formulasi doktrin mungkin terdapat rintanganrintangan yang besar, tetapi seringkali identitas seseorang bisa sampai pada suatu pengertian yang jujur, sederhana, dan sangat memuaskan, dengan jalan memperbandingkan catatan-catatan mengenai kehidupan yang tafakur, disiplin, tingkah laku, dan manfaatnya ${ }^{43}$.

Iman tidak melulu menuntut suatu pemahaman yang mendalam akan ajarannya. Lebih dari itu, sebenarnya iman lebih menuntut pada pencarian dan penemuan identitas diri di dalam komitmen hidup religius seseorang. Seperti Kornelius yang mungkin saja tidak memenuhi seluruh syarat untuk bisa disebut sebagai bagian dari jemaat yang beriman kepada Kristus terkait asal-usul etnisnya, demikian pula para ekspenganut ADS walaupun bisa dikatakan masih muda dalam iman Kristiani, tetapi penghayatan hidup mereka sebenarnya sudah sejak lama dipengaruhi nilai-nilai injili tersembunyi yang terdapat di dalam ajaran leluhur mereka itu. Saat mereka menerima diri dibaptis, pola perilaku luhur yang telah mereka hayati memeroleh justifikasi di dalam iman kepada Kristus.

\section{PENUTUP}

Gerak dinamis Roh Kudus tidak pernah bisa terduga. Gerak dinamis yang tidak terduga itu juga dialami Gereja Katolik Keuskupan Bandung. Jika awalnya pelayanan sakramental dan pastoral diberikan hanya untuk menjaga dan merawat orang-orang Belanda Katolik dan dilanjutkan sejumlah pendatang, ${ }^{44}$ seiring dinamika sosial, politik, dan budaya setempat, pelayanan sakramental dan pastoral pun harus diberikan kepada penduduk setempat. Gerak mendekat ke arah penduduk setempat tak didasarkan pada upaya memengaruhi, apalagi me- 
maksa. ${ }^{45}$ Layaknya hembusan Roh Kudus yang sede-mikian lembut, yang tidak banyak disadari banyak orang pada umumnya, iman Kristiani menjumpai dan mengenalkan dirinya sendiri kepada sejumlah orang pribumi Sunda yang merasa terpesona dengan kesaksian iman akan Kristus itu. Dalam hal ini jelas bahwa menjadi Gereja bukan berarti sibuk dengan identifikasi apa yang asli dan murni dalam Gereja dan menghapus segala macam unsur lain yang terdapat dalam budaya lokal. Gereja akan tercipta jika iman dan konteks yang bermacam-macam itu berkumpul bersama dan berbagi pengalaman dengan sikap saling menghargai.

Orientasi perkembangan Gereja Perdana dikatakan semakin meluas dan melebar ke 'ujung dunia'. ${ }^{46}$ Sebagaimana para Rasul dibimbing secara perlahan-lahan oleh Roh Kudus untuk keluar dari tenis Yahudi, Yudais-me, dan teritori Palestina lalu diutus sampai ke ujung bumi, demikian pulalah misi Gereja, yakni keluar dari diri sendiri menuju kepada 'yang lain'. ${ }^{47}$

Upaya dialog menjadi suatu proses yang terus-menerus dan menuntut pertobatan dari setiap pribadi yang terlibat di dalam proses tersebut. Dalam kisah perjumpaan Petrus dan Kornelius, Allah menawarkan suatu bentuk dialog sehingga bukan sekadar pemaksaan suatu ajaran tertentu kepada pribadi tertentu yang terjadi, melainkan suatu perluasan dan pembukaan wawasan iman.

\section{CATATAN AKHIR}

1 Tom Gunadi (ed.), Tonggak-tonggak Sejarah Gereja Katolik Keuskupan Bandung (Bandung: PT. Intergrafika, 1984), 93.

2 R.F. Bhanu Viktorahadi, Menyusuri Dinding Waktu. Memaknai Sejumlah Narasi Pertobatan di Nusantara dan Bumi Parahyangan dari Sudut Pandang Kisah Para Rasul (Yogyakarta: Kanisius, 2017), 30.

3 W.P. Straathof OSC (ed.), Agama Djawa Sunda (Hartina Agama Djawa Sunda), Nr.2 reeks J.S.R. (A), (Garut, Juni 1970), 5.

4 Didin Komarudin, "Agama Djawa Sunda (ADS) Religious Movement," dalam el Harakah Vol.19 No.1 (2017): 98.

5 Kepustakaan Nasional RI: Katalog dalam Terbitan (KDT), 2013. Cigugur-Miniatur Pluralisme
Secara perlahan-lahan Petrus bisa masuk ke dalam situasi dan kompleksitas konflik antara dirinya, Kornelius, dan jemaat KristenYahudi sehingga iman yang dimiliki bukanlah suatu bentuk pemaksaan, melainkan suatu wujud pilihan bebas pribadi yang dilanjutkan dengan komitmen serius.

Petrus sanggup 'mempertobatkan' diri sendiri dengan membuka hati dan budinya untuk kemudian 'mempertobatkan' Kornelius dan jemaat Yahudi. Buah dinamika pertobatan itu tidaklah mutlak pemahaman keyakinan yang langsung mendalam. Akan tetapi, di sana terjadi ruang komunikasi dan dialog yang dibuka sehingga masing-masing sungguh bisa mengenal dan akhirnya memahami. Inilah yang disebut dialog kehidupan yang kualitasnya pasti lebih tinggi dibandingkan upaya-upaya yang kerap dilabeli kristenisasi. Dinamika itu pula yang sebenarnya diharapkan terjadi pada Gereja Katolik Keuskupan Bandung saat menerima saudara-saudara eks-penganut ADS, sehingga iman yang mereka pilih itu akhirnya bukanlah sekadar akibat tuntutan kondisi, melainkan lambat laun sungguh menjadi suatu komitmen yang datang dan tumbuh dari dalam diri mereka secara bebas. Pada gilirannya, komitmen itu akan menumbuhkan identitas diri sebagai bagian jemaat yang mengimani Kristus sekaligus yang tidak melepaskan diri dari konteks asal-usulnya. Sehingga iman itu bukan sekadar tempelan.

Indonesia, (Bogor: Lembaga Pengkajian Kebudayaan Nusantara, 2013), 33.

6 Kepustakaan Nasional, 2013, 46-47.

7 A. Eddy Kristiyanto, "Madraisme: Memapar Khazanah Rohani Agama Djawa Sunda" dalam Spiritualitas Dialog: Narasi Teologis tentang Kearifan Religius (Kanisius: Yogyakarta, 2010), 188.

8 Ajip Rosidi, Manusia Sunda (Jakarta: Inti Idayu Press, 1985), 10

9 W.P. Straathof OSC, "Agama Djawa Sunda: Sedjarah, Adjaran, dan Tjara Berpikirnja-I," BASIS No.7 tahun XX/April (1972), 221.

10 Basuki Nursananingrat, Purwawisada Agama Djawa Sunda (Bandung, Juni 1964), 14.

11 Terjemahan Sudarman, Sampuraning Hirup Sajatining Mati: Konsep Kesempurnaan Hidup Menurut Ajaran Agama Djawa Sunda (Bandung: Skripsi UNPAR, 2001), 12. 
12 W.P. Straathof OSC (ed.), Agama Djawa Sunda, Nr.14 reeks J.S.R. (A), Bandung, Juli (1971), 1-2.

13 Terjemahan Sudarman, 2011, 12-13.

14 W.P. Straathof OSC (ed.), Tjatatan-2 Mengenai Agama Djawa Sunda, Nr.13 reeks J.S.R. (A), Bandung, Juli (1971), 3.

15 P. Djatikusumah, Pemaparan Budaya Spiritual Paguyuban Adat Cara Karuhun Urang (Kuningan, 1995), 6.

16 Didin Komarudin, "Agama Djawa Sunda (ADS) Religious Movement," dalam el Harakah Vol.19 No.1 (2017), 100.

17 Lihat Pramoedya Ananta Toer (penyunting), Cerita dari Digul, (Jakarta: Kepustakaan Populer Gramedia (KPG), 2001), viii-ix.

18 Ign. Eddy Putranto OSC (ed.), Semakin Mandiri Menjadi Ragi (Bandung: Panitia Perayaan 80 tahun Keuskupan Bandung, 2012), 111

19 W.P. Straathof OSC (ed.), Sadjarah Ngadegna Agama Djawa Sunda (ADS), Nr. 1 reeks J.S.R. (A), Garut, Juni (1970), 11-15.

20 Ign. Eddy Putranto OSC (ed.), 2012, 112

21 A.M. Basuki Nursananingrat, Umat Katolik Cigugur (Yogyakarta: Kanisius, 1977), 25.

22 W.P. Straathof OSC (ed.), Masa Peralihan Agama Djawa Sunda ke Agama Katolik Bagian II, Nr.12 reeks J.S.R. (A), (Bandung, Maret 1971), 1.

23 Ign. Eddy Putranto, 2012, 113.

24 A.M. Basuki Nursananingrat, 1977, 28.

25 Ign. Eddy Putranto OSC, 2012, 114.

26 W.P. Straathof OSC (ed.)., Sedjarah dan Pokok-2 Adjaran Agama Djawa Sunda/ADS, Nr.10 reeks J.S.R. (A) (Garut, Februari 1971), 13-14.

27 Tentang pembagian ini bisa dilihat antara lain Joachim Gnilka, Pietro e Roma, (Brescia: Paideia Editrice, 2003), 84; Ds. H.v.d. Brink, Kisah Para Rasul (Jakarta: PT. BPK Gunung Mulia, 2008), 160-173

28 Kaisarea Maritima adalah sebuah kota di tepi laut. Kota ini didirikan Herodes Agung pada 22 sM. Pada zaman kekuasaan kekaisaran Romawi, kota ini menjadi ibukota provinsi Roma di Palestina. Oleh karena itu, tak mengherankan jika di kota pesisir tersebut banyak tinggal para pembesar dan pejabat kekaisaran Romawi.

29 Daniel Marguerat, La prima storia del cristianesimo. Gli Atti degli apostoli (Ciniselo Balsamo, Milano: Edizioni San Paolo s.r.l., 2002), 113-114.

30 Giancarlo Biguzzi, I discorsi degli Atti degli apostoli, (Roma: Pontificia Università Urbaniana, manuskrip, 2004), 12.

31 Giancarlo Biguzzi, 2004, 12.

32 J. Roloff, Apostolat - Verkündigung - Kirche (Gütersloh, 1965), 222-226.

33 Ign. Eddy Putranto, 2012, 113.

34 Herman Dooyeweerd, In the Twilight of Western Thought (Philadelphia: The Presbyterian and Reformed Publishing Co., 1960), 1-34.

35 Y.C. Kristiono Hartanto (ed.), Sing Jadi Ragi. Buku Kenangan Dasa Warsa Pentahbisan Uskup
Bandung (Bandung: PT. Intergrafika, 1994), 162 163.

36 Hasil Sinode Keuskupan Bandung 2015, Sehati sejiwa berbagi sukacita (Bandung, 2015), 5-6.

37 Hasil Sinode Keuskupan Bandung 2015, Sehati sejiwa berbagi sukacita (Bandung, 2015), 10.

38 Hasil Sinode Keuskupan Bandung 2015, Sehati sejiwa berbagi sukacita (Bandung, 2015), 3.

39 Stephanus Djunatan, "Krisis Identitas Diri dan Kegiatan Misioner Gereja" dalam Keluar dari Diri Sendiri, Prosiding Seminar-Lokakarya Memperingati 50 Tahun Ad Gentes (Bandung: Unpar Press, 2017), 63.

40 Lam Wing-hung, "Patterns of Chinese Theology" dalam The Bible and Theology in Asian Contexts: An Evangelical Perspective on Asian Theology, eds. Bong Rin Po \& Ruth Eshenaur (Taichung, Taiwan: Asia Theological Association, 1984), 339.

41 Daniel J. Adams, Teologi Lintas Budaya. Refleksi Barat di Asia (Jakarta: PT. BPK Gunung Mulia, 1992), 122

42 Lihat Bruce Nicholls, "A Living Theology for Asian Churches: Some Reflections on the Contextualization-Syncretism Debate" dalam The Bible and Theology in Asian Contexts: An Evangelical Perspective on Asian Theology, eds. Bong Rin Po \& Ruth Eshenaur (Taichung, Taiwan: Asia Theological Association, 1984), 134.

43 Thomas Merton, Mystics and Zen Masters (New York: Dell Pub. Co., 1969), 209.

44 R.F. Bhanu Viktorahadi, 19-20

45 R.F. Bhanu Viktorahadi, 29

46 Hal ini ditegaskan Philipe H. Menoud melalui tulisannya, "Le plan des Actes des Apôtres." JésusChrist et la Foi (Neuchâtel-Paris, 1975), 46: "melalui perjalanan misi, Injil sudah mencapai semua kategori yang mungkin dijangkau manusia."

47 Raymundus Sudhiarsa, "Misi itu Vitalitas Gereja Ad Gentes" dalam Komisi Teologi KWI, Kompendium Konsili Vatikan II - Konteks Indonesia (Yogyakarta: Kanisius, 2012), 224-242.

\section{DAFTAR RUJUKAN}

Adams, D.J. Teologi Lintas Budaya. Refleksi Barat di Asia. Jakarta: PT. BPK Gunung Mulia, 1992.

Biguzzi, G. I discorsi degli Atti degli Apostoli. Roma: Pontificia Universitas Urbaniana (manuskrip), 2004

Djatikusumah, P. Pemaparan Budaya Spiritual Paguyuban Adat Cara Karuhun Urang. Kuningan: (tanpa penerbit), 1995. 
Djunatan, S. "Krisis Identitas Diri dan Kegiatan Misioner Gereja." Keluar dari Diri Sendiri, Prosiding SeminarLokakarya Memperingati $50 \mathrm{Th}$ Ad Gentes. Bandung: Unpar Press, 2017.

Dooyeweerd, H. In the Twilight of Western Thought. Philadelphia: The Presbyterian and Reformed Publishing Co., 1960.

Dupont, J. "La Conclusion des Actes et son rapport à l'ensemble de l'ouvrage de Luc.” J. Kremer (ed.), Les Actes des apôtres. Traditions, rédaction, théologie, BEThL 48, Gembloux-Leuven University Press, 1979.

Eddy Putranto OSC, Ign (ed.). Bertekun Menabur Benih. Penggembalaan Gereja Katolik Keuskupan Bandung. Masa awal sampai dengan 1949, Bandung, 2012.

, Semakin Mandiri Menjadi Ragi. Perkembangan Gereja Katolik Keuskupan Bandung 19502011. Bandung, 2012.

Gnilka, J. Pietro e Roma. Brescia: Paideia Editrice, 2003.

Gunadi, T. Tonggak-tonggak Sejarah Gereja Katolik Keuskupuan Bandung. Bandung: PT. Intergrafika, 1984.

Hartanto, Y.C.K. (ed.). Sing Jadi Ragi. Buku Kenangan Dasawarsa Pentahbisan Uskup Bandung. Bandung: PT. Intergrafika, 1994.

Hasil Sinode Keuskupan Bandung 2015. Sehati sejiwa berbagi sukacita. Bandung: 2015.

Komarudin, D. "Agama Djawa Sunda (ADS) Religious Movement." El Harakah Vol.19 No.1 Tahun 2017.

Marguerat, D. La prima storia del cristianesimo. Gli Atti degli Apostoli. Cinisello Balsamo (Milano): Edizioni San Paolo, 2002.
Marshall, I.H. Aacts and the "Former Treatise." B.W. Winter dan A.C. Clarke (eds.), The Book of Acts in its First Century Setting. Grand RapidsCarlisle: Eerdmanns-Paternoster, 1993.

Menoud, Phillipe H., "Le plan des Actes des Apôtres." Jésus-Christ et la Foi. Neuchâtel-Paris, 1975.

Merton, T. Mystics and Zen Masters. New York: Dell Pub. Co., 1969.

Nicholls, B. "A Living Theology for Asian Churches: Some Reflections on the Contextualization-Syncretism

Debate." The Bible and Theology in Asian Context: An Evangelical Perspective on Asian Theology. Bong Rin Po \& Ruth Eshenaur (eds.). Taichung, Taiwan: Asia Theological Association, 1984.

Nursananingrat, B. Umat Katolik Cigugur, Yogyakarta: Kanisius, 1977.

Purwawisada Agama Djawa Sunda. Bandung (tanpa penerbit), 1964.

Roloff, J. Apostolat - Verkündigung - Kirche, Gütersloh, 1965.

Rosidi, A. Manusia Sunda. Jakarta: Inti Idayu Press, 1985.

Straathof, W.P., Osc, "Agama Djawa Sunda: Sedjarah, Adjaran dan Tjara Berpikirnja I-IV.” BASIS No.7,9,10,11 Tahun XX/April, Juni, Juli. Yogyakarta: Agustus 1971.

\section{Sadjarah Ngadegna} Agama Djawa Sunda (ADS), Nr. 1 reeks J.S.R. (A). Garut: (manuskrip), Juni 1970.

Agama Djawa Sunda (Hartina Agama Djawa Sunda), Nr. 2 reeks J.S.R. (A). Garut: (manuskrip), Juni 1970. 
. Sedjarah dan Pokok-2

Adjaran Agama Djawa Sunda/ADS, Nr.10 reeks J.S.R. (A). Garut: (manuskrip), Februari 1971.

Masa Peralihan Agama

Djawa Sunda ke Agama Katolik Bagian II, Nr.12 reeks J.S.R. (A). Bandung: (manuskrip), Maret 1971.

. Tjatatan-2 Mengenai

Agama Djawa Sunda, Nr.13 reeks J.S.R. (A). Bandung: (manuskrip), Juli 1971.

Agama Djawa Sunda, Nr.14 reeks J.S.R. (A). Bandung: (manuskrip), Juli 1971.

Sudarman. Sampuraning Hirup Sajatining Mati: Konsep Kesempurnaan Hidup Menurut Ajaran Agama Djawa Sunda. Bandung: Universitas Katolik Parahyangan (skripsi), 2001.
Sudhiarsa, R. "Misi itu Vitalitas Gereja - Ad Gentes." Komisi Teologi KWI, Kompendium Konsili Vatikan II Konteks Indonesia.Yogyakarta: Kanisius, 2012.

Toer, P. A. Cerita dari Digul. Jakarta: Kepustakaan Populer Gramedia (KPG), 2001.

v.d. Brink, Ds. H. Kisah Para Rasul. Jakarta: PT. BPK Gunung Mulia, 2008.

Viktorahadi, R.F.B. Menyusuri Dinding Waktu. Memaknai Sejumlah Narasi Pertobatan di Nusantara dan Bumi Parahyangan dari Sudut Pandang Kisah Para Rasul. Yogyakarta: Kanisius, 2017.

Wing-hung, L. "Patterns of Chinese Theology." The Bible and Theology in Asian Context: An Evangelical Perspective on Asian Theology. Bong Rin Po \& Ruth Eshenaur (eds.). Taichung, Taiwan: Asia Theological Association, 1984. 